\title{
A preliminary study of the porosity and permeability of limestones and sandstones in the Jameson Land area, central East Greenland
}

\author{
Lars Stemmerik
}

The Upper Palaeozoic - Mesozoic sequence in the Jameson Land area (figs 1,2) is well known from numerous studies carried out since GGU initiated mapping of the area in 1968 (e.g. Clemmensen, 1980a, b; Surlyk et al., 1973, 1984, 1986a; Surlyk, 1983, 1987; Heinberg \& Birkelund, 1984). Based on these studies, Surlyk et al. (1986b) proposed that a number of Upper Permian - Cretaceous formations have a reservoir potential. Sandstone and limestone samples from these and a few additional formations (fig. 2) have been analysed for porosity and air-permeability. The analyses, all performed on surface samples or shallow cores, rep- resent the first numerical approach to the evaluation of reservoir properties in the Jameson Land - Scoresby Land basin, and form a preliminary background for a more detailed reservoir study presently being undertaken by GGU.

The analyses were carried out commercially by the Core Analysis Laboratory of the Geological Survey of Denmark (Haslund, 1985; Springer, 1986). Air-permeability, He-porosity and grain density were measured conventionally on uncleaned 1 " $\times 1$ " plugs after humidity drying.

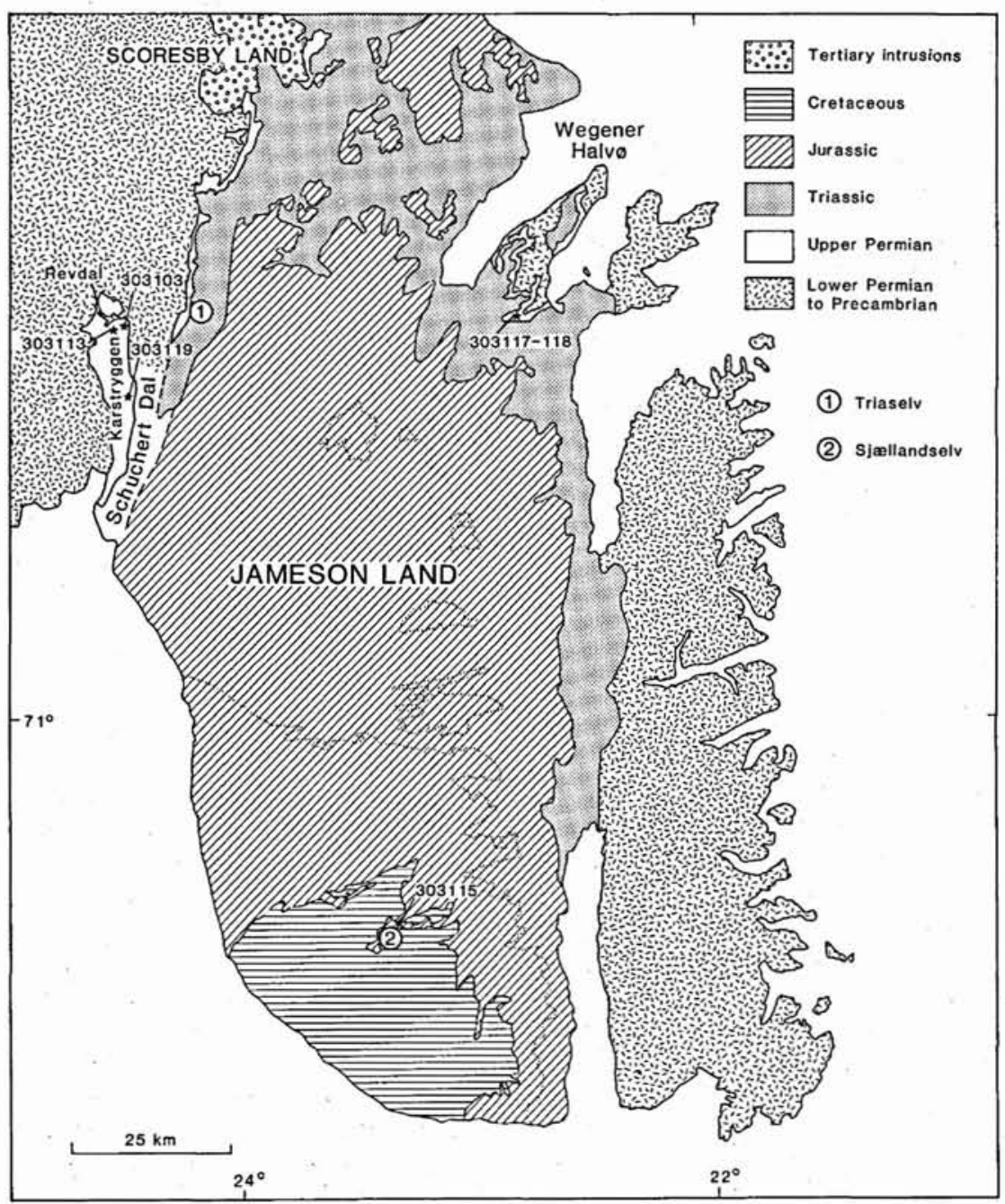

Fig. 1. Geological map of Jameson Land showing position of localities mentioned in the text and drilling locations. The geology is simplified from Surlyk et al. (1973). 


\section{Upper Permian}

Within the Upper Permian sequence potential reservoir rocks are confined to the limestones of the Karstryggen and Wegener Halvø Formations (Surlyk et al., 1986a; Hurst et al., in press) and the sandy part of the Schuchert Dal Formation (Surlyk et al., 1986b). The juxtaposition of the Karstryggen and Wegener Halvø limestones with the potential source rocks of Ravnefjeld Formation makes these some of the more interesting targets in the subsurface. Therefore most of the analysed material comes from these two formations.

The Karstryggen Formation is $10-100 \mathrm{~m}$ thick and includes a variety of hypersaline limestones and calcium sulphate evaporites (Surlyk et al., 1986a, b; Stemmerik, 1987). The analysed material includes 13 limestone sam- ples from a shallow core (GGU 303101) drilled in the middle part of the formation near Revdal (fig. 1). The results of the analyses are shown in fig. $3 \mathrm{a}$.

The Wegener Halv $\emptyset$ Formation varies in thickness from less than $5 \mathrm{~m}$ centrally in the basin to more than $150 \mathrm{~m}$ along the margin (Surlyk et al., 1986a). The thick platform sequences are dominated by algal mounds in the lower part, and bryozoan-cement mounds and shallowwater limestones in the upper part (Surlyk et al., 1986a; Hurst $e t$ al., in press). The analysed material includes 33 core samples from bryozoan-cement mounds at Wegener Halvø (GGU 303117, 303118) and Karstryggen (GGU 303113), and five samples from an algal mound at Karstryggen (core GGU 303119) (for location see fig. 1). The results of the analyses are shown in fig. $3 \mathrm{~b}$.
Fig. 2. Schematic stratigraphic section of the Upper Permian Mesozoic sequence of Jameson Land. Main lithology and maximum thickness shown. $\mathrm{R}$ indicates potential reservoir and $S$ indicates potential source rock. Modified from Surlyk et al. (1986b).
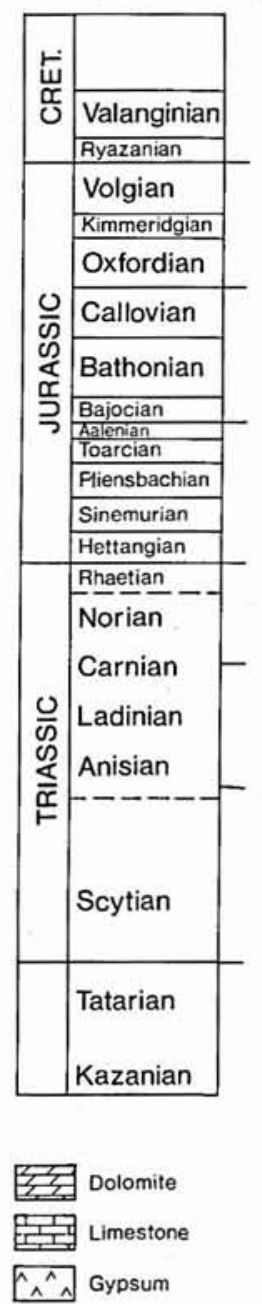

\section{JAMESON LAND}

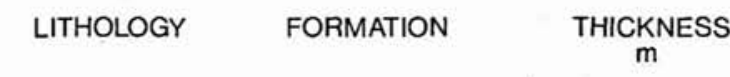

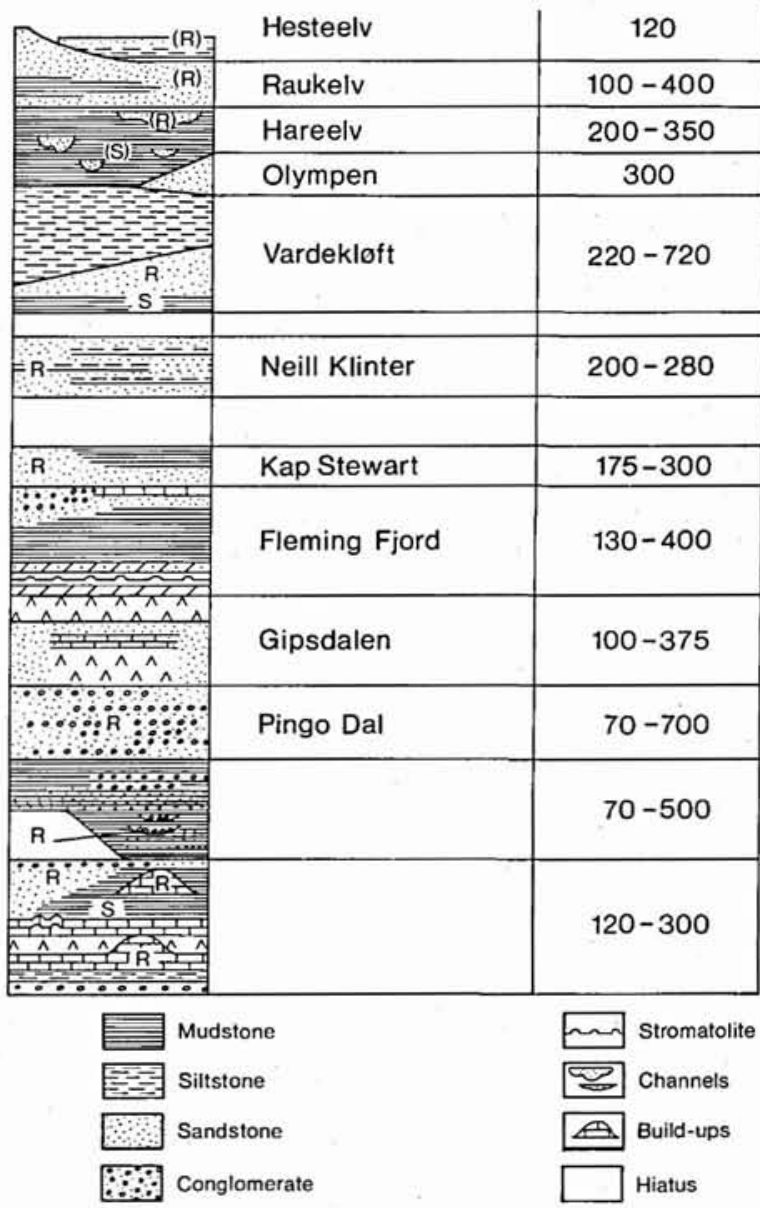



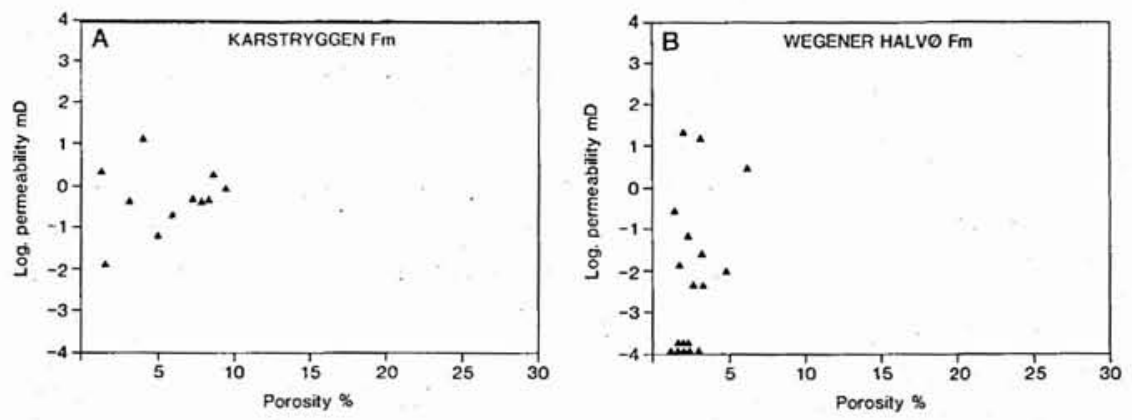

Fig. 3. Porosity-permeability plots of the Upper Permian Lower Jurassic formations mentioned in the text.
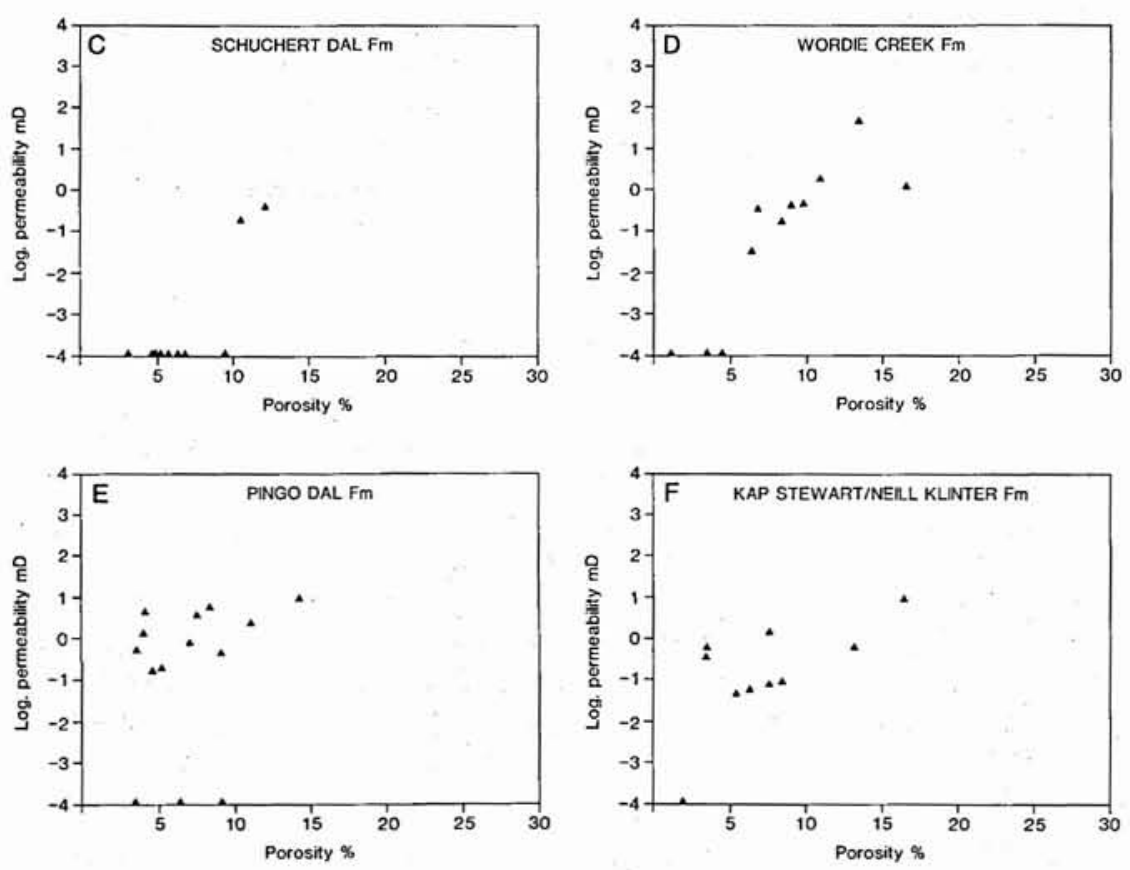

Schuchert Dal Formation. The sandy part of the Schuchert Dal Formation, the Bredehorn Member, varies in thickness from $50-150 \mathrm{~m}$. It consists of fine- to mediumgrained micaceous sandstone deposited in short-headed fan deltas (Surlyk et al., 1986a). The analyses were performed on surface samples from the east slope of Schuchert Dal (fig. 1). The results are shown in fig. 3c.

\section{Triassic}

Within the Triassic sequence it is suggested that potential reservoir rocks include sandstones from the Wordie Creek and Pingo Dal Formations.

Wordie Creek Formation. Potential reservoir rocks are confined to large submarine sandy channels within the otherwise shale-dominated unit. The largest channel sandstone recognized is more than $20 \mathrm{~m}$ thick and several kilometres across. Most of the analyses were car- ried out on surface samples from this sandstone unit in Triaselv (fig. 1). However, a few samples from thin sandstone beds elsewhere were also included. The results are shown in fig. $3 \mathrm{~d}$.

The Pingo Dal Formation varies in thickness from $70 \mathrm{~m}$ centrally in the basin to $700 \mathrm{~m}$ along the margins (Clemmensen, 1980a, b). The formation is dominated by two wedge-shaped members composed of alluvial-fan sandstones and conglomerates. The analysed material only includes surface samples from the northern part of the region. Sandstones from the two members have similar porosity/permeability values (fig. $3 \mathrm{e}$ ).

\section{Jurassic}

The Jurassic succession outcrops in most of Jameson Land (fig. 1). Hence potential reservoirs are limited to the southern part where the Jurassic rocks are covered 
Fig. 4. Porosity-permeability plots of the Middle Jurassic Lower Cretaceous formations mentioned in the text.
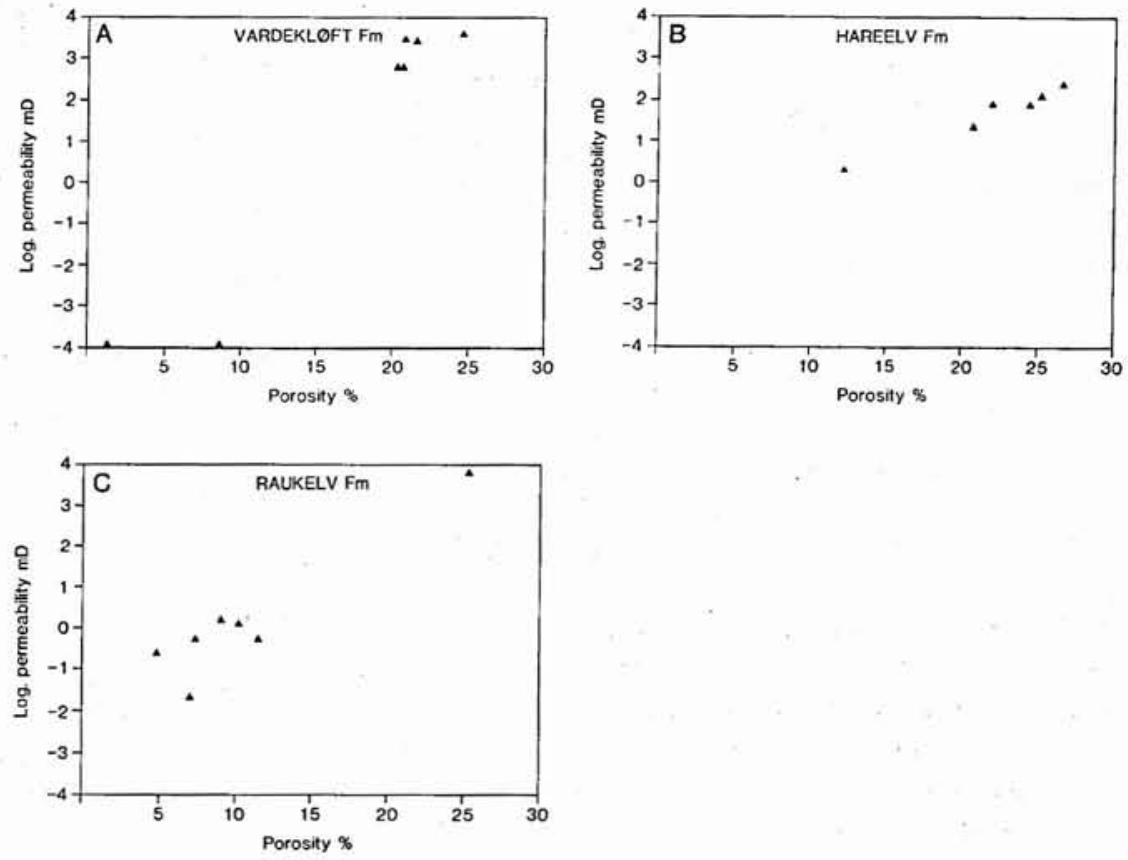

by Cretaceous sediments (fig. 1). However, the Lower Jurassic Kap Stewart and Neill Klinter Formations may be buried deeply enough to form potential reservoirs also in northern Jameson Land. In addition to the Lower Jurassic formations, the Middle Jurassic Vardekløft Formation and the Upper Jurassic Hareelv Formation include potential reservoir rocks. The late Jurassic succession is mainly of interest for possible future offshore exploration.

Kap Stewart and Neill Klinter Formations. The material available from these formations is sparse and relatively poor and only includes surface samples from the south eastern margin of the basin. Here, the Kap Stewart Formation is $200 \mathrm{~m}$ thick and composed of fluviatile sandstones. The Neill Klinter Formation is $250-300 \mathrm{~m}$ thick and dominated by tidal deposits. Analyses from the two formations are presented together in fig. $3 \mathrm{f}$.

Vardekløft Formation. Within this formation potential reservoir rocks are found in the sandy Pelion Member. This member consists of a large wedge-shaped body of medium- to coarse-grained shelf sandstone, which increases in thickness northwards from $10 \mathrm{~m}$ to more than 600 'm (Surlyk et al., 1973; Heinberg \& Birkelund, 1984). The analyses were carried out on surface samples from the northern part of the region. The results are shown in fig. $4 \mathrm{a}$.

Hareelv Formation. Potential reservoir rocks in the Ha- reelv Formation are restricted to slope and deep-shelf gully sandstones enclosed in the otherwise shale-dominated unit (Surlyk, 1987). The sand bodies are up to 50 $\mathrm{m}$ thick and hundreds of metres wide, and may be more than $5 \mathrm{~km}$ long in downcurrent direction (Surlyk, 1987). Samples from core GGU 303115 drilled in Sjællandselv (fig. 1) were analysed. The results are shown in fig. $4 \mathrm{~b}$.

\section{Cretaceous}

Both the Raukelv and the Hesteelv Formations include sandstones that may be potential reservoirs. However, the distribution of the Cretaceous sediments in Jameson Land (fig. 1) prevents them being reservoirs here, so they are mainly of interest for possible future offshore exploration. During this study only material from the Raukelv Formation was available.

The Raukelv Formation is estimated to be $300 \mathrm{~m}$ thick (Surlyk et al., 1973). It consists of thick, homogeneous or large-scale cross-bedded sandstone units alternating with shaly siltstones. The materials analysed are surface samples of sandstones from Sjællandselv (fig. 1). The results are shown in fig. $4 c$.

\section{Discussion}

The use of surface material to predict reservoir properties in the subsurface is very difficult, particularly where carbonates are involved. The main problem is the 
timing of different diagenetic events in relation to hydrocarbon generation and migration.

It is evident from figs $3 a$ and $3 b$ that the analysed Upper Permian limestones have very low values for both porosity and permeability. However, diagenetic studies show that much of the primary porosity is filled by a late high-temperature cement (Surlyk et al., 1986a; Hurst et al., in press). The reservoir potential in the subsurface is therefore strongly dependent on the age of this cement relative to hydrocarbon migration.

The sandstones show highly variable porosities and permeabilities, both from formation to formation, and within a single formation. It is evident that the most promising analytical values are recorded from the Vardekløft and Hareelv Formations (figs $4 \mathrm{a} \& 4 \mathrm{~b}$ ). Also it is obvious that the porosities and permeabilities are generally higher in the Jurassic and Cretaceous sandstones compared with the Upper Permian and Triassic values (figs 3, 4). However, detailed diagenetic studies are needed to see whether this pattern is related to differences in the primary lithology, thermal maturity and subsidence depth, or if it is related to preferential secondary leaching of carbonate cement in the Jurassic Cretaceous sandstones during uplift. Also, the Triassic and Upper Permian feldspar-rich sandstones may have increased secondary porosity in their deeper buried settings in the subsurface.

This preliminary study of potential reservoir rocks will be followed by more detailed diagenetic studies of the Upper Permian Karstryggen and Wegener Halvø Formations, the Lower Jurassic Kap Stewart and Neill Klinter Formations (see Dam, 1988), and the Lower Cretaceous Raukelv Formation.

\section{References}

Clemmensen, L. B. 1980a: Triassic rift sedimentation and palaeogeography of central East Greenland. Bull. Grønlands geol. Unders. 136, $72 \mathrm{pp}$.

Clemmensen, L. B. 1980b: Triassic lithostratigraphy of East Greenland between Scoresby Sund and Kejser Franz Josephs Fjord. Bull. Grønlands geol. Unders. 139, 56 pp.

Dam, G. 1988: Sedimentological studies of the fluviatile-shallow marine Upper Triassic to Lower Jurassic succession in
Jameson Land, East Greenland. Rapp. Grønlands geol. Unders. 140.

Haslund, O. 1985: Conventional core analysis for GGU. Selected samples: Jameson Land. Unpubl. intern. rep. Geol. Surv. Denmark 34, 12 pp.

Heinberg, C. \& Birkelund, T. 1984: Trace-fossil assemblages and basin evolution of the Vardekløft Formation (Middle Jurassic, central East Greenland). J. Paleont. 58, 362-397.

Hurst, J. M., Scholle, P. A. \& Stemmerik, L. in press: Submarine cemented bryozoan mounds, Upper Permian, Devondal, East Greenland. In Geldsetzer, H. (edit.) Reef case histories. Mem. Can. Soc. Petrol. Geol.

Springer, N. 1986: Conventional core analysis for GGU. Samples from Jameson Land. Unpubl. intern. rep. Geol. Surv. Denmark 42, 13 pp.

Stemmerik, L. 1987: Cyclic carbonate and sulphate from the Upper Permian Karstryggen Formation, East Greenland. In Peryt, T. M. (edit.) The Zechstein facies in Europe. Lecture Notes in Earth Sciences 10, 5-22. Berlin: Springer.

Surlyk, F. 1977: Stratigraphy, tectonics and palaeogeography of the Jurassic sediments of the area north of Kong Oscars Fjord, East Greenland. Bull. Grønlands geol. Unders. 123, $56 \mathrm{pp}$.

Surlyk, F. 1983: Source rock sampling, stratigraphical and sedimentological studies in the Upper Palaeozoic of the Jameson Land basin, East Greenland. Rapp. Grønlands geol. Unders. 115, 88-93.

Surlyk, F. 1987: Slope and deep shelf gully sandstones, Upper Jurassic, East Greenland. Bull. Amer. Assoc. Petrol. Geol. 71, 464-475.

Surlyk, F., Callomon, J. H., Bromley, R. G. \& Birkelund, T. 1973: Stratigraphy of the Jurassic - Lower Cretaceous sediments of Jameson Land and Scoresby Land, East Greenland. Bull. Grønlands geol. Unders. 105, 76 pp.

Surlyk, F., Hurst, J. M., Marcussen, C., Piasecki, S., Rolle, F., Scholle, P. A., Stemmerik, L. \& Thomsen, E. 1984: Oil geological studies in the Jameson Land basin, East Greenland. Rapp. Grønlands geol. Unders. 120, 85-90.

Surlyk, F., Hurst, J. M., Piasecki, S., Rolle, F., Scholle, P. A., Stemmerik, L. \& Thomsen, E. 1986a: The Permian of the western margin of the Greenland Sea - a future exploration target. In Halbouty, M. T. (edit.) Future petroleum provinces of the world. Mem. Amer. Assoc. Petrol. Geol. 40, 629-659.

Surlyk, F., Piasecki, S. \& Rolle, F. 1986b: Initiation of petroleum exploration in Jameson Land, East Greenland. Rapp. Grønlands geol. Unders. 128, 103-121. 